\title{
Problem Based-Learning: Method of Enhancing and Encouraging the Motivation of English Department Students at English Pragmatics Class
}

\author{
${ }^{1}$ Faculty of Humanities Universitas Andalas, Padang, Sumatera Barat, Indonesia \\ ${ }^{2}$ Faculty of Humanities Universitas Andalas, Padang, Sumatera Barat, Indonesia \\ ${ }^{3}$ Faculty of Medicine Universitas Andalas Padang Sumatera Barat, Indonesia \\ ${ }^{4}$ Polytechnic of Kemenkes RI III, Jakarta, Indonesia \\ *Corresponding author. Email: ikerevita@hum.unand.ac.id
}

Ike Revita ${ }^{1, *}$ Reschie Andriani ${ }^{2}$ Farah Anindya Zalfikhe ${ }^{3}$ Rovica Trioclarise

\begin{abstract}
Problem-based learning (PBL) is one of the teaching methods implemented at Universitas Andalas to achieve the objectives of teaching and accelerate the teaching and learning process. PBL is considered suitable to encourage students to be more active in the class. This article reports research on the implementation of PBL in English Pragmatics Class at the English Department, Universitas Andalas. The objectives are to assure the effectiveness of this method in enhancing the students' motivation in learning English Pragmatics. The data were collected by distributing questionnaires to the students at the end of the semester. The PBL was applied by dividing the students into small groups, with the guidance of a mentor, for four months. The responses of the students to the questionnaires reveals that problem-based learning is effective in both enhancing the students' motivation and encouraging students participation in the learning process.
\end{abstract}

Keywords: English Pragmatics, English Department Students, Problem-based learning

\section{INTRODUCTION}

English Pragmatics is one of the compulsory courses in the English Department which provides students with information about Pragmatics. Pragmatics is the study of language related to the context [1] [2]. Thus, in this course, the students are expected to be able to use language contextually as the outcome.

According to Permenristek Dikti No. 44 of 2005, lectures are carried out based on the student, in which the students are stimulated and motivated to be more active than the lecturers. For this reason, one of the methods that is based on the students is selected in English Pragmatics Class. Problem-Based Learning is becoming a choice since it is of great possibility to be applicable. The method was tried out to the students in this English Pragmatics course at the English Department Universitas Andalas.

\subsection{Related Work}

Based on the booklet written by Institute for Educational Development and Quality Assurance (LP3M) Universitas Andalas, there are nine methods of teaching and learning processes based on students. They are 1) Small Group Discussion (SGD); 2) Role- Play and Simulation; 3) Discovery Learning; 4) Self- Directed Learning; 5) Cooperative Learning; 6) Contextual Learning (CL); 7) Problem Based Learning (PBL); 8) Collaborative Learning (CbL); and 9) Project Based Learning (PjBL). Each of these methods has its characteristics depending on the students.

Problem-based learning as the method is not only used to help students gain a better comprehension of the teaching materials but also to improve their competence in creating scientific reasoning [3]. In this problem- based learning, students are also guided to solve the problem and make some reflection. Cognitive skills, such as inquiry, communication, and connection can be 
developed by using their experiences. Furthermore, the ability to solve meaningful problems, relevance, and contextual can be sharpened [4].

The implementation of the problem-based learning method can be one solution to stimulate students to have critical thinking. It is due to their experiences are involved in gaining an understanding of the concept. Moreover, this method has led students to be more creative as well [5].

\subsection{Paper Structure}

The rest of the paper is organized as follows. Section 2 talks about the concept of problem-based learning and how the method is implemented in the class. A brief explanation of the course is given in this section.

\section{BACKGROUND}

\subsection{Problem-based learning at English Pragmatics}

English Pragmatics is one of the compulsory subjects in the English Department. All students, regardless of their tendency, linguistics, or literature, are required to take this three-credit course. English Pragmatics is a prerequisite subject offered in the previous semester (Semester V). Students are allowed to take this course if they have taken and passed the Syntax and Semantics Courses. This means that all English Department students in semester V are required to take this English Pragmatics course as long as the requirements are met.

Previously, this course was called Pragmatics which was offered for seventh-semester students (VII). The revision of the curriculum then made this course offered earlier. This means that students who take this course are a year earlier than their seniors. In terms of conceptual ability and prerequisite courses, it is not a problem because changes in the course offer times also occur in many courses. However, the ability and strength to understand concepts related to the culture of using English as an important point in learning English Pragmatics become the challenge. Therefore, an appropriate learning method is preferred to make the students motivated.

At the English Pragmatics class, students are introduced to basic concepts related to language use. In other words, through English Pragmatics, students have been directed to understand everything related to how the language is used as a communication tool based on context. Besides, students are also encouraged to be aware of the language phenomena encountered in their environment. Thus, the learning outcome is that the students are expected to be able to understand the basic aspects related to language use as well as to identify the real language reality that occurs within the framework of using language as a communication tool.

Students were also taught how language is used in interactions involving participants from different languages and cultures. In communication. some points are considered so that the communication can run well, especially in cross-language and cross-cultural contexts. Furthermore, how to speak in the corridors of politeness is also part of the topics discussed in this course. Speech act and its implementation is the core business in the English Pragmatics Course. Therefore, students who have passed this course are expected to have a good understanding related $d$ the concepts of the use of language. It must be in line with the ability to analyze and implement it in everyday life.

Currently, the English Pragmatics course in the English Department consists of two parallel classes taught by a different team of lecturers. Each class consists of two to three lecturers. So far, the two teams have used the same syllabus and have always coordinated to discuss the learning and assessment process. It implies that even though they are taught by three different teams and lecturers, there are no significant differences between classes. Even, learning techniques are not much different, except for the way of teaching because each lecturer has his art in delivering material.

Regarding the learning model, teaching English Pragmatics courses tends to be student-centered learning. Students are conditioned to be more active, in class or outside the classroom, to identify and solve problems arranged in such away. Thus, students are relatively active in seeking material and materials to enrich their respective understanding and knowledge. Indirectly, students have been equipped with and are carrying out an educational process characterized by long-life learning that mastering hard skills, soft skills, and life skills. Studying and learning in such a way is also following what [6] argues that students have to make a sense of information for themselves if they are to learn anything. 
In the English Pragmatics class, students are directed to be active and independent. As an adult learner (student), they are no longer subjected to 'scribbling' and 'cursing' knowledge, which are just waiting for information from the lecturer. Students are stimulated and motivated to actively seek solutions to problems related to the English Pragmatics course. It is expected that stimulation and motivation can help achieve maximum learning. One form of stimulating and motivating is giving the students home works for every topic at each meeting [7]. The home assignment is in the form of a reading report written by each student and written in a 1-2 page report, 1.5 spaces, with the format, Introduction, Content, and References (minimum 3). This homework is not given to the group that presents its paper at that time. The independence and activeness of the students are realized by designing learning in the form of seminars. Students are divided into several groups and each given one lecture topic/material. Each group is responsible for explaining this material according to the scheduled time. This material is also presented in a simple paper with a predetermined format.

The activeness and independence of students do not diminish the role of lecturers. On the contrary, lecturers here act more as partners and facilitators. Lecturers are also required to have competence and responsibility from the beginning to the end of the semester so that there is no impression of being hands-off because it is studentcentered learning. In short, learning English Pragmatics for the early stages has been quite successful in implementing Students Centered Learning. This can be seen from several indications when this course was still called Pragmatics, namely, (1) Students begin to enjoy learning Pragmatics (based on unstructured surveys and interviews conducted with students from 2007 to 2009 in 2010, 2011, 2012); (2) Students' understanding of Pragmatics is getting better (it can be seen from the final score of students for the Pragmatics course who get B + on average); (3) From year to year there is an increase in the number of students taking Linguistics, especially Pragmatics as a scientific concentration in research for their thesis (lastly, nearly $60 \%$ of the total English Literature students who have been allowed to take Seminar courses (Semester 8).

Along with the development of science and technology, the implementation of learning for the English Pragmatics course has not changed much. In general, the format given is still the same as the SCL learning system in the form of seminars. However, to motivate students so that they are not empty-headed, reading reports still becomes one activity done by the students.

Unfortunately, the sophistication of technology has not been used positively by some students. They are said to be "lazy" [8]. They only need to take the task of reading from the internet and then just copy and paste it. Related to that case, the reading report was used to be in the form of a reading, then it was converted into a slide form which they then printed out in the handout format. The number is limited to only six slides.

This effort has not yet shown the maximum results. This can be seen from the fact that there are still many students doing plagiarism. Ironically, a group of students presenting the topic of lecture material tend to just copy the information from the book. They do not understand the essence of the information. When being confirmed, the response is mostly just silent or busily looking for answers on their smartphones. In fact, in one batch (2016), there was a very sad incident where almost a third of them were declared to have received a standard final score, which was between C-B grade. Previously, some students passed with good grades, on average in numbers. $75(\mathrm{~B}+)$ and above. For this reason, it is necessary to carry out a kind of classroom action research that can stimulate and trigger students' motivation that correlates with the ability in English Pragmatics based on the final score obtained. Based on the above phenomena, it is necessary to do and try out different and "challenging" learning methods for students taking this English Pragmatics course. The challenge is in terms of the length of time the students regularly get in contact with English. These students have spent a shorter time than the seniors who have been studying English for three years. This course is offered for those who have only been two years or in four semesters of intensively dealing with English. Thus, problem-based learning (PBL) became the choice. It is expected that there will be an increase in the number of students' abilities and masteries of learning materials. Besides, students' motivation should also be increased. That learning is for them is expected to become a basic principle so that personal awareness arises to improve self - quality. 


\section{RESULT AND DISCUSSION}

Problem Based Learning is one method in the learning process that is Student-Centered Learning (SCL). In Problem Based Learning, students learn together in a small group through two main learning activities, namely small group discussions facilitated by a tutor and independent study [9]. Universitas Andalas as one of the public universities in Indonesia has implemented the SCL method in the teaching and learning process. Rector of Universitas Andalas has made SCL as being outlined in Rector Regulation Number 3 of 2016 concerning the obligation to implementing SCL at Universitas Andalas.

For this reason, the English Department supports this program by encouraging lecturers to apply SCL. The English Pragmatics course has applied the SCL method in the teaching and learning process but it is not comprehensive yet. In some topics and meetings, TCL is still used. One of the reasons for this is because the English Pragmatics course must also strengthen some basic concepts that require explanations and descriptions from the lecturers. The application of Teacher-Centered Learning which is dominant in several meetings indirectly creates a less positive atmosphere for students. This happens because students become accustomed to depending on the lecturer's explanation. Even if they are asked to work in groups, usually only certain students are active while others are more likely to be a good listener. As a result, the learning process did not run optimally.

For this reason, the SCL Problem Based Learning (PBL) method was tested so that students can be actively involved and they are also able to apply concepts when given cases related to linguistic phenomena. In this English Pragmatics class, students are then divided into several small groups, namely 3-4 people per group, and then the PBL method is applied.

In contrast to what is done in the Faculty of Medicine, where learning uses a block system facilitated by a tutor for each group, in this English Pragmatics course, a class is divided into six small groups and facilitated by the faculty team lecturers. In principle, the implementation of PBL remains based on what is described in the Practical Handbook for the Implementation of Student-Centered Learning (SCL).

There are several steps prepared before this PBL is conducted. They are a) the lecturers identify and determine learning topics that will use PBL; b) Lecturers prepare scenarios to stimulate students regarding the application of PBL; c) The lecturer divides the students into 6 groups consisting of 3-4 people per group; d) The Lecturer Team ensures that the group is ready for learning using the PBL method; e) The Lecturer Team ensures that each group member can learn independently, and f) The Lecturer Team provides feedback to students regarding their role in the teaching and learning process and efforts to achieve learning objectives.

The implementation carried out in this PBL adopts and adapts the concepts carried out at the Faculty of Medicine Universitas Andalas. If in FK students are given a kind of module, in the English Pragmatics class we do not do it but only give a kind of short guide which is shared with students through I-learn and WhatsApp media.

The steps in implementation are 1) All students were asked to study independently related to the topic in the week before the topic/learning material is discussed, 2) Students sat in groups each in the form of a circle which has a moderator and a journalist for each group, and 3) At the beginning of the meeting, two groups were randomly selected as the responsible group for the meeting topic, 4) The first group then described their work steps following the seven jumps stages are:1) Identify terminology and concepts that the responsible group thinks they did not understand, 2) Introducing basic concepts related to the topic/concept and how the responsible group interprets the concept, and 3) Brainstorming to discuss this concept together in which every group responds in the form of their understanding of the concept, 4) The second responsible group reviewed the results of the discussion and delivered them; 5) The Lecturer Team ensured that learning objectives were focused, achievable, comprehensive, and precise and aligns information related to the material.

In the teaching and learning process activities in the English Pragmatics course, it was tried to be applied as an effort to stimulate students to be actively involved. As a subject that is applicable and challenging because it relates to language and its use in society, English Pragmatics should ideally be enjoyed by all students. Weak motivation because it is triggered by incentives and weak student willingness also affects the fulfillment of learning outcomes. It is necessary for stimulation and encouragement.

Internal encouragement means that students are triggered and encouraged to have the enthusiasm to continue to seek and seek to improve their 
understanding of English Pragmatics. External encouragement means that the choice of method, provision of facilities and infrastructure as well as a selection of lecture time are aspects that are considered. However, there are some of these external factors which cannot be touched by the punishment of the system. For example, a schedule that is assessed as 'infertile'. This is related to the system at Unand which has set lecture schedules centrally. Unand determines the lecture schedule so that the lecturer must follow the predetermined schedule. In addition, the lecture time during the day, coupled with hot weather and the lack of cooling, caused some students to become unfocused and sleepy.

This became one of the obstacles to increasing external encouragement. For this reason, we need a method that can reduce unmet external variables. Through the PBL method with various existing submethods, it is hoped that it can boost student motivation and competence.

From the evaluation of the last 3 years, the students' scores in the English Pragmatics course can be categorized as quite good because the failure rate is very small. However, from the distribution of the existing values, the maximum value gain (A) is still limited because the largest number is in the range of values $B$ to $\mathrm{B}+$ (range of values is $70-74$ and 75-79). For this reason, from the results of the PBL method trial, the level of success and understanding of students was getting better. Although in the beginning, students seemed to have difficulty in the adjustment process, along the way, students began to get used to the patterns and methods applied.

There were some slight changes in the division of the group. Previously, the members of each group were in line with the change of the method. The students may choose their mates and these students tend to choose their groupmate based on the ease of communication. This way of choosing group members for some topics are determined by the lecturers.

\section{CONCLUSION}

Implementing problem-based learning in English Pragmatics Class is turned out to provide its own fun for students. This can be seen from the responses the students gave during the lecture. At the early stages, students seemed to have difficulties. This is triggered by their inability to solve problems that originate from problems or data. So far, students tend to be exposed to theories and concepts followed by some relatively less updated examples.

Using a problem-based learning method made students who take the English Pragmatics course stimulated and more motivated. This is indicated by the results of a survey conducted which showed that almost $70 \%$ of students liked this method. According to them, this method is more challenging. In addition, they are also increasingly motivated because everything departs from reality and linguistic phenomena. Through the method using problembased learning, students in the English Pragmatics class feel that their understanding of the topics gets deeper.

Considering the implementation of the method, there are some other methods that can be selected by the lecturers as the options in the learning process. The choice of a method is absolutely based on the class context. This means that students, topics, and infrastructure need to be considered.

The English Pragmatics class has implemented problem-based learning for students in 2020. The same method can be used in other courses or in the same course but with different students. In addition, the use of the problem-based learning method also needs to consider the topic because it cannot be applied to all topics. In short, the problem-based learning method is one of the many options in SCL that lecturers can use to meet their learning outcomes.

\section{AUTHOR'S CONTRIBUTION}

This paper presents some improvements done in English Pragmatics Class is the way to enhance and to motivate the students in learning English Pragmatics. Speaking is not easy but communicating smoothly might not be able to be done by all speakers. Thus, by applying the method of problem-based learning, the learning outcome designed can be achieved. Furthermore, this method can also be the model for other parallel classes in the English Department, specifically and other study programs, generally.

\section{ACKNOWLEDGMENTS}

This work was supported by Institute for Educational Development and Quality Assurance or Lembaga Pengembangan Pendidikan dan Penjaminan Mutu (LP3M) Universitas Andalas. 


\section{REFERENCES}

[1] Ike Revita, Pragmatik:Kajian Tindak Tutur Permintaan Lintas Bahasa. Padang: Fakultas Ilmu Budaya Universitas Andalas, 2013.

[2] J.Austin, Austin J. L. -How to Do Things With Words.pdf. Oxford: The Clarendon Press, 1962.

[3] Noly Shofiyah, Fitria Eka Wulandari. Model Problem Based Learning (Pbl) Dalam Melatih Scientific Reasoning Siswa. Vol 3, No 1. 2018.DOI: http://dx.doi.org/10.26740/jppipa.v3n1 .p33-38.

[4] Marhamah Saleh. Strategi Pembelajaran Fiqh dengan Problem-Based Learning. Jurnal Ilmiah DIDAKTIKA. Agustus 2013 VOL. XIV NO. 1, 190- 220.

[5] Rizal Abdurrozak, Asep Kurnia Jayadinata, Isrok 'atun. Pengaruh Model Problem Based Learning Terhadap Kemampuan Berpikir Kreatif Siswa. Jurnal Pena Ilmiah: Vol. 1, No, 1. 2016

[6] Paul Ramsden, Learning to Teach in Higher Education, London: Routledge, 1992.

[7] Revita, Ike. 2016. Peningkatan Kemampuan Bahasa Inggris Dosen dan Mahasiswa di Lingkungan Universitas Andalas: Masalah Dan Solusi'. Laporan Penelitian. Tidak Dipublikasi. Padang: Universitas Andalas

[8] Kompas, 22 Februari 2012

[9] Tim LP3M UNAND. 2016. Panduan StudentsCentered Learning. Padang: Unand. 